\title{
Comparison of multiplex, ELISA and immunofluorescence for detecting autoantibodies in JIA patients
}

\author{
Paul T Fawcett ${ }^{*}$, Victoria L Maduskuie, Carlos D Rose \\ From 2011 Pediatric Rheumatology Symposium sponsored by the American College of Rheumatology \\ Miami, FL, USA. 2-5 June 2011
}

\section{Purpose}

Detection of antinuclear antibodies has traditionally been performed by immunofluorescence (IFA) on fixed culture cells or tissues with reactivity being reported as a fluorescence pattern associated to one or more nuclear antigens. For this study, we compared results from IFA testing with a multiplex antinuclear antibody assay on a panel of patient serum samples previously evaluated by 3 commercial ANA ELISAs.

\section{Methods}

Patient samples: Serum samples from 164 pediatric patients with JIA (82 pauciarticular, 63 polyarticular, 19 systemic) and 20 healthy children (autodonor samples) were tested according to manufacturer's instructions for all methods. All specimens were stored at $-80^{\circ} \mathrm{C}$. Testing using 3 ANA ELISAs, IFA and multiplex were performed in batch to minimize freeze thaw cycles. IFA was performed on fixed HEp-2 cell substrate slides with fluorescence pattern and titer determined by an experi- enced medical technologist. ELISAs included the following antigen mixtures: Sm, RNP, SSA, SSB, Scl-70, JO-1, dsDNA, histones and centromere. The multiplex assay contained substrate beads for individual quantitative detection of antibodies to all of the antigens contained in the ELISAs and qualitative detection of ANA.

\section{Results}

See table 1.

As previously reported, ELISA testing did not correlate with IFA results. Multiplex showed a similar discrepancy with IFA when assessed qualitatively: 48 multiplexed positive JIA versus 98 IFA positives. When higher titer IFA positives $(\geq 1: 160)$ were compared with multiplex, findings were similar: 22 multiplex positive versus 52 IFA positive.

\section{Conclusion}

Data obtained from this study indicates that neither ELISA nor multiplex testing, using individually quantifi-

Table 1 Evaluation of IFA, multiplex and ELISA antinuclear antibody testing in pediatric JIA patients

\begin{tabular}{|c|c|c|c|c|c|c|}
\hline \multirow[b]{3}{*}{ Types of JIA } & \multirow[b]{3}{*}{ \# of Samples (n-184) } & \multicolumn{5}{|c|}{ Number testing positive } \\
\hline & & IFA & Multiplex & & ELISA & \\
\hline & & Hep-2 & Microparticle & A. & B. & C. \\
\hline Pauciarticular & 82 & 62 & $27^{*}(3)+{ }^{* *}(7)$ & $4+{ }^{*}(1)$ & $32+*(5)$ & $52+{ }^{*}(8)$ \\
\hline Polyarticular & 63 & 34 & $16^{*}(2)+* *(1)$ & $10+*(4)$ & $30+*(14)$ & $46+{ }^{*}(21)$ \\
\hline Systemic & 19 & 3 & $5+*(4)$ & $1+{ }^{*}(1)$ & $6+{ }^{*}(4)$ & $12+*(12)$ \\
\hline All JIA with $\geq 1: 160$ IFA & 164 & 52 & 22 & & & \\
\hline Normals & 20 & 6 & $1+* *(2)$ & $0+* *(2)$ & $4+*(1)$ & $5+*(2)$ \\
\hline
\end{tabular}

Numbers in parentheses: * IFA Negative(s) that were Positive. ${ }^{*}$ IFA Positives that were Equivocal 
able antigens, perform the same as IFA to screen pediatric patients with JIA. The lack of agreement between test methods may reflect differences in the array of antigens present in the various assays. Results suggest that both multiplex and ELISA can not replace IFA for routine screening in JIA. However, unlike the ELISAs, the multiplex assay has the advantage of allowing quantitative determination of autoantibodies to each individual nuclear antigen which makes it a superior choice for reflex testing for antibodies to individual nuclear antigens.

\section{Disclosure}

Paul T. Fawcett: None; Victoria L. Maduskuie: None; Carlos D. Rose: None.

Published: 13 July 2012

doi:10.1186/1546-0096-10-S1-A117

Cite this article as: Fawcett et al:: Comparison of multiplex, ELISA and

immunofluorescence for detecting autoantibodies in JIA patients. Pediatric

Rheumatology 2012 10(Suppl 1):A117.
Submit your next manuscript to BioMed Central and take full advantage of:

- Convenient online submission

- Thorough peer review

- No space constraints or color figure charges

- Immediate publication on acceptance

- Inclusion in PubMed, CAS, Scopus and Google Scholar

- Research which is freely available for redistribution

Submit your manuscript at www.biomedcentral.com/submit 